\title{
Nanomolar concentrations and rapid turnover of dissolved free amino acids in seawater: agreement between chemical and microbiological measurements
}

\author{
Jed A. Fuhrman ${ }^{1} \&$ Randolph L. Ferguson ${ }^{2}$ \\ ${ }^{1}$ Marine Sciences Research Center, State University of New York, Stony Brook, New York 11794, USA \\ ${ }^{2}$ National Marine Fisheries Service, Southeast Fisheries Center, Beaufort Laboratory, Beauiort, North Carolina 28516, USA
}

\begin{abstract}
Dissolved free amino acids (DFAAs) are important sources of carbon and nitrogen for marine bacteria. Past studies of DFAAs have reported inconsistencies between chemical (chromatographic) and microbiological (uptake kinetics) measures of concentrations. We found no systematic differences in this temperate zone study of summer coastal and winter continental shelf seawater. Concentrations of individual DFAAs were in the 1 to $15 \mathrm{nM}$ range and turnover times averaged $1 \mathrm{~h}$ or less in summer and about $6 \mathrm{~h}$ in winter. Chemical assays by high pressure liquid chromatography (HPLC) employed collection and filtration techniques minimizing ubiquitous DFAA contamination. Kinetics assays utilized trace-metal clean techniques and extremely low additions (0.02 to $3 \mathrm{nM})$ of tritiated DFAAs. Kinetic data, corrected for respiration and based on HPLC-measured specific activities of added amino acids, indicated some evidence for multiphasic uptake kinetics, even at subnanomolar additions. The general agreement between the HPLC and microbial techniques was consistent with rapid DFAA tumover and bacterial uptake rates approaching the maximum rate of the highest affinity systems, i.e. the uptake affinity constants $\left(K_{1}\right)$ were smaller than the ambient concentrations.
\end{abstract}

\section{INTRODUCTION}

Up to one half of total marine primary production can be assimilated by bacterioplankton (Hagström et al. 1979, Fuhrman \& Azam 1980, 1982, Williams 1981). Because bacteria are probably unable to take up large macromolecules directly, the assimilated material is in the form of smaller molecules such as sugars, amino acids, and peptides. With protein making up about half of the typical algal biomass (Parsons et al. 1977), amino acids and small peptides must be important sources of carbon and nitrogen for marine bacteria. Numerous studies have borne out the particular significance of the DFAAs (e.g. Andrews \& Williams 1971, Crawford et al. 1974, Williams \& Yentsch 1976, Ferguson \& Sunda 1984).

Critical to the study of DFAA utilization are accurate data on the concentration of individual or total DFAAs. These can be measured chemically (usually by liquid or gas chromatography), or indirectly estimated microbiologically by a kinetics assay that determines the sum of the ambient concentration $\left(S_{n}\right)$ plus the halfsaturation uptake constant $\left(\mathrm{K}_{\mathrm{t}}\right)$ (Parsons \& Strickland 1962, Wright \& Hobbie 1965). Few workers have done both types of measurements, and some of them have reported higher concentrations by the chemical approach, indicating that some of the chemically measured DFAAs are somehow unavailable for bacterial uptake (Burnison \& Morita 1974, Dawson \& Gocke 1978) or that those chemical techniques introduce DFAA contaminants (Ferguson \& Sunda 1984). A more recent study by Jørgensen \& Søndergaard (1984) found good agreement between the chemical (high pressure liquid chromatography; HPLC) and microbiological assays in 3 lakes and 2 highly eutrophic coastal marine sites, where total DFAA concentrations were reported to be 155 to $720 \mathrm{nM}$.

In this study we compare HPLC analysis and a microbiological assay of DFAA concentrations in both eutrophic and non-eutrophic coastal seawater. We analyzed DFAA concentrations by HPLC and uptake kinetics in Long Island Sound (shore-based laboratory) and 
on board ship at locations in the New York Bight. For both kinds of measurements we were very careful to avoid sample contamination by amino acids or by toxic trace metals. With the precautions described below: we found agreement in results of the chemical and microbiological assays.

\section{MATERIALS AND METHODS}

Shipboard work was conducted on board the R/V Researcher on 8 to 11 February 1984 in the New York Bight. Samples were collected at 15 to $20 \mathrm{~m}$ depths from off Montauk Point, New York on 8 February, and from the Christiansen Basin on 9 to 11 February (exact locations presented with results). Ambient water temperature was 4 to $6^{\circ} \mathrm{C}$. Trace metal clean techniques have been described previously (Ferguson \& Sunda 1984); all samples were collected with acid-washed teflon-coated 30 l Go-Flo bottles (General Oceanics, Miami) suspended from a non-metallic (Kevlar) cable; samples were removed from the bottles under a laminar flow hood and kept in well-rinsed acid-washed teflon bottles (for kinetics assays) or polyethylene Whirlpak bags (for HPLC analysis). Comparisons with the teflon bottles showed that rinsed polyethylene bags did not introduce DFAAs or significantly inhibit bacterial uptake of DFAAs.

Kinetics assays at sea were performed as described by Ferguson \& Sunda (1984). Most were run at 7 to $10^{\circ} \mathrm{C}$. Each assay included triplicate additions of amino acids at 5 concentrations $(0.1$ to $3 \mathrm{nM}$ for individual amino acids and 0.3 to $10 \mathrm{nM}$ for mixed amino acids). Kinetic parameters were calculated by nonlinear regression of turnover rate on concentration of added substrate (Li 1983). Concentrations of DFAAs in the tritiated stock solutions (New England Nuclear) were measured by HPLC as described below. With the exception of the serine stock, we found more DFAAs (unlabelled contaminants) in the stocks than expected from specific activity data supplied by the manufacturer. Kinetics parameters from New York Bight experiments were corrected for a $20 \%$ average respiration estimate (Palumbo et al. 1983). This estımate was also in accordance with measured glutamic acid respiration on 8 February (see methodology below). Note that under- or overestimation of respiration does not effect the calculation of $K_{t}+S_{n}$ by kinetics analysis as long as the percent respiration is constant over the concentration range tested; it does effect calculation of turnover time.

Kinetics analyses in lab experiments at Stony Brook (summers 1983 and 1984) were performed with samples collected in acid-washed plastic bottles from a pebble beach at Crane Neck Point, New York, on Long
Island Sound $\left(40^{\circ} 55.3^{\prime} \mathrm{N}, 73^{\circ} 09.3^{\prime} \mathrm{W}\right)$. Samples were kept in a seawater-temperature $\left(18\right.$ to $\left.20^{\circ} \mathrm{C}\right)$ lighted incubator (ca $100 \mu \mathrm{E} \mathrm{m}^{-2} \mathrm{~s}^{-1}$ ). Tritiated alanine (New England Nuclear or Amersham) was added to subsamples in rinsed polyethylene Whirlpak bags at 5 to 7 concentrations ( 0.1 to $10 \mathrm{nM}$ ). Incubations lasted 10 to $20 \mathrm{~min}$. Assays were terminated by filtration on to $0.45 \mu \mathrm{m}$ pore size Millipore filters, followed by three $1 \mathrm{ml}$ filtered seawater rinses. Respiration was measured as loss of radioactive water from filtrates $(0.5 \mathrm{ml})$ upon freeze-drying; the amount of respired tritium was added to that retained on the filter for calculation of total uptake. Kinetics parameters were determined from modified Lineweaver-Burke plots (Parsons \& Strickland 1962, Wright \& Hobbie 1965) by linear regression and by non-linear regression.

DFAAs were analyzed by HPLC of seawater samples using a modification of the ortho-phthaldialdehyde derivatization technique of Mopper \& Lindroth (1982). Ten ml samples were gently filtered through a copiously distilled-water-rinsed $0.45 \mu \mathrm{m}$ pore size $25 \mathrm{~mm}$ diameter mixed ester cellulose Millipore filter in a nitric acid-washed PVC and stainless steel filtration manifold (Hoefer Scientific, San Francisco). One ml subsamples were derivatized with $10 \mu \mathrm{l}$ of a reagent consisting of $12.5 \mathrm{mg}$ ortho-phthaldialdehyde, $250 \mu \mathrm{l}$ 2-mercaptoethanol, and $250 \mu \mathrm{l} 1 \mathrm{M}$ sodium borate buffer ( $\mathrm{pH} 13)$. After exactly $1 \mathrm{~min}, 5 \mu \mathrm{l}$ of $10 \%$ ( $\mathrm{vol} / \mathrm{vol}$ ) acetic acid was added to stop the reaction, and $250 \mu \mathrm{l}$ was injected into the HPLC (Spectra Physics model 8700 , Kratos model FS-970 fluorescence detector set at $340 \mathrm{~nm}$ excitation and $>410 \mathrm{~nm}$ emission, Spectra Physics model 4270 integrator). The chromatographic column had dimensions of $4.6 \times 100 \mathrm{~nm}$ and was commercially packed with Microsorb $3 \mu \mathrm{m}$ spherical C18 bonded silica (Rainin Instruments, Woburn, Massachusetts). Mobile phases were (A) $50 \mathrm{nM}$ sodium acetate, pH 5.8, with $2 \%$ tetrahydrofuran, and (B) methanol; the elution gradient was 25 to $50 \%$ B from 0 to $6 \mathrm{~min}$, held at $50 \% \mathrm{~B}$ from 6 to $8 \mathrm{~min}, 50$ to $60 \% \mathrm{~B}$ from 8 to $10 \mathrm{~min}$, held at $60 \%$ from 10 to $12 \mathrm{~min}, 60$ to $80 \% \mathrm{~B}$ from 12 to $13 \mathrm{~min}$, at $80 \%$ from 13 to $15 \mathrm{~min}$, returned from 80 to $25 \% \mathrm{~B}$ from 15 to $16 \mathrm{~min}$. Reagent blanks were filtered HPLC-grade water or Sargasso seawater aged in the dark. Further details of the HPLC methodology are presented by Fuhrman \& Bell (1985).

\section{RESULTS}

\section{Long Island Sound}

The range of the HPLC-measured alanine concentrations in 4 samples collected in June was 4.2 to $14.5 \mathrm{nM}$ (Table 1). In 3 of 4 samples, the calculated $K_{t}+S_{n}$ for 
Table 1. HPLC-measured alanine concentrations and uptake parameters for Long Island Sound

\begin{tabular}{|c|c|c|c|c|}
\hline Date & $\begin{array}{l}\text { HPLC-measured } \\
(\mathrm{nM})^{*}\end{array}$ & $\begin{array}{c}\mathrm{K}_{t}+\mathrm{S}_{n} \\
(\mathrm{nM})\end{array}$ & $\begin{array}{l}\text { Turnover } \\
\text { time (h) }\end{array}$ & $\begin{array}{l}\text { Utilization rate } \\
\mu \mathrm{gC} 1^{-1} \mathrm{~h}^{-1} \cdots\end{array}$ \\
\hline 2 Jun 1983 & $4.2 \pm 0.3$ & $6.9^{\cdots}$ & 0.4 & 0.38 \\
\hline 7 Jun 1984 & $14.5 \pm 2.5$ & $7.7^{\cdots}$ & 0.9 & 0.58 \\
\hline 15 Jun 1984 & $5.1 \pm 0.8$ & $31.4^{\cdots}$ & 0.8 & 0.23 \\
\hline 29 Jun 1984 & $7.4 \pm 0.1$ & 9.2 & 1.2 & 0.22 \\
\hline \multicolumn{5}{|c|}{$\begin{array}{l}\quad \text { Means } \pm 1 \text { SE. Numbers in parentheses are number of replicates } \\
\therefore \text { Possible multiphasic kinetics } \\
\cdots \text { From mean HPLC-measured concentration. Nitrogen utilization rate is } 14 / 36 \text { times the shown value }\end{array}$} \\
\hline
\end{tabular}

alanine was higher than the concentration measured by HPLC, as might be expected (Table 1). The estimated turnover times of ambient substrate were quite short, about 0.4 to $1.2 \mathrm{~h}$ (Table 1 ). In 3 of the 4 samples there was an indication of multiphasic uptake kinetics, that is, the turnover time increased less than linearly with increasing added substrate concentrations. This is indicative of multiple uptake mechanisms, each with different $K_{t}$ and $V_{\max }$ values (Azam \& Hodson 1981). In these samples, the non-linearity makes the estimate of $K_{1}+S_{n}$ (from linear regressions of all the data) higher than would be obtained from just the lower (closer to ambient) added concentrations. Given the small number of replicates and added substrate levels in these experiments, however, it is not reasonable to derive kinetic parameters from a subset of the data; therefore only the results for the whole data sets are reported.

\section{New York Bight}

Concentrations of DFAAs in the New York Bight also were in the low nanomolar range. On 8 Febnuary, when 2 independent kinetics assays using glutamic acid and 11 HPLC analyses were performed on the same sample, the $K_{1}+S_{n}$ values were 5.1 and $6.0 \mathrm{nM}$, while the HPLC-measured concentrations averaged 2.9 , with a standard error of 0.5 . Data from the comparisons of the chemical and microbiological assays, including those with single or mixed amino acids, and those spiked with alanine or mixed amino acids indicated that the 2 measurements were within a factor of 3 of each other over a broad concentration range (Table 2). In 5 samples the HPLC-measured concentrations were higher and in 6 samples the $K_{t}+S_{n}$ values were higher. In all but 1 sample, the 2 measures were within 2 standard errors of each other, indicating that they were not significantly different (Table 2).

We made 2 attempts (with alanine and the amino acid mixture) to determine the effect of added amino acids on kinetic estimates of $\mathrm{K}_{l}+\mathrm{S}_{\mathrm{n}}$ and HPLC estimates of $S_{n}$. A 10 nM spike of alanine increased the HPLC-measured concentration by $9.9 \mathrm{nM}$ but was not detected in the kinetics assay. In the second experiment a spike of $65 \mathrm{nM}$ mixed amino acids increased the HPLC result by $42.4 \mathrm{nM}$ and the kinetics result by $64.7 \mathrm{nM}$ (Table 2). The failure of the kinetics assay to detect a doubling of the alanine concentration may have been due to the poor precision associated with these $\mathrm{K}_{\mathrm{t}}+\mathrm{S}_{\mathrm{n}}$ estimates at low near-ambient concentrations (note large standard errors in Table 2).

Data from almost all of the kinetics assays for the New York Bight samples appeared to be consistent with single pairs of $K_{1}$ and $V_{\max }$ parameters operative in the concentration ranges studied (i.e. single straight lines in Modified Lineweaver-Burke plots). However, a serine analysis indicated multiphasic kinetics, even at sub-nanomolar added concentrations (Fig. 1).

Turnover times for the New York Bight samples ranged from 3 to $12 \mathrm{~h}$ (data not shown). Most of these samples were incubated at 3 to $5 \mathrm{C}^{\circ}$ above the ambient temperature of $6^{\circ} \mathrm{C}$, so these turnover rates were probably elevated above in situ rates. One sample incubated at ambient temperature (from off Montauk Point, serine assay) had an average $6.6 \mathrm{~h}$ turnover time (duplicates: 6.0 and $7.2 \mathrm{~h}$ ). The total serine utilization rate calculated from the HPLC-measured concentration, was $0.64 \mu \mathrm{g} \mathrm{Cl}^{-1} \mathrm{~d}^{-1}$.

\section{DISCUSSION}

The most important result of this study was the similarity of chemical and biological measurements of DFAA concentrations. Thus, there is no evidence from these measurements that the 2 assays disagree to a significant extent. In the kinetics assay, however, the concentration and affinity constant are conjoined and the comparison with HPLC is not direct.

Ideally the $K_{t}$ value is determined by difference of kinetically measured $K_{t}+S_{n}$ and chemically measured $S_{n}$. Both HPLC and kinetic assays of DFAAs are subject to error, however, and the kinetic estimates of $K_{1}+S_{n}$ 
Table 2. Station and concentration data for New York Bight samples

\begin{tabular}{|c|c|c|c|c|c|c|}
\hline Date & Location & Depth $(m)$ & $\begin{array}{c}\text { Bacteria } \\
\left(10^{6} \mathrm{ml}^{-1}\right)\end{array}$ & Amino acid & $K_{t}+S_{n}(n M)$ & $\begin{array}{c}\text { Conc. by HPLC } \\
\text { (nM) } \cdots\end{array}$ \\
\hline 8 Feb 1984 & $\begin{array}{l}4050.6^{\prime} \mathrm{N} \\
7149.7^{\prime} \mathrm{W}\end{array}$ & 20 & 0.69 & Glutamic & $5.6(0.5)$ & $2.9(0.5)$ \\
\hline 9 Feb 1984 & $\begin{array}{l}4022.5^{\prime} \mathrm{N} \\
7333.3^{\prime} \mathrm{W}\end{array}$ & 15 & 1.05 & $\begin{array}{l}\text { Glutamic } \\
\text { Serine } \\
\text { Mixture }\end{array}$ & $\begin{array}{r}5.0(5.7) \\
1.4(0.8) \\
37.9(7.1)\end{array}$ & $\begin{array}{r}2.1 \\
4.5 \\
24.7\end{array}$ \\
\hline 10 Feb 1984 & $\begin{array}{l}4022.0^{\prime} \mathrm{N} \\
7333.6^{\prime} \mathrm{W}\end{array}$ & 15 & 0.99 & $\begin{array}{l}\text { Alanine }(\mathrm{A}) \\
\mathrm{A}+10 \mathrm{nM} \\
\mathrm{A}<3 \mu \mathrm{m} \cdots \\
\text { Glutamic } \\
\text { Mixture }\end{array}$ & $\begin{aligned} 8.6 & (6.5) \\
6.8 & (5.1) \\
6.6 & (3.3) \\
1.6 & (0.3) \\
23.8 & (12.0)\end{aligned}$ & $\begin{array}{r}3.0 \\
12.9 \\
8.6 \\
2.1 \\
9.0\end{array}$ \\
\hline 11 Feb 1984 & $\begin{array}{l}4025.9^{\prime} \mathrm{N} \\
7344.7^{\prime} \mathrm{W}\end{array}$ & 15 & 1.03 & $\begin{array}{l}\text { Mixture (M) } \\
M+65 \mathrm{nM}\end{array}$ & $\begin{array}{ll}29.3(6.6) \\
94.0(36.9)\end{array}$ & $\begin{array}{l}32.6(5.5) \\
75.0(7.1)\end{array}$ \\
\hline
\end{tabular}

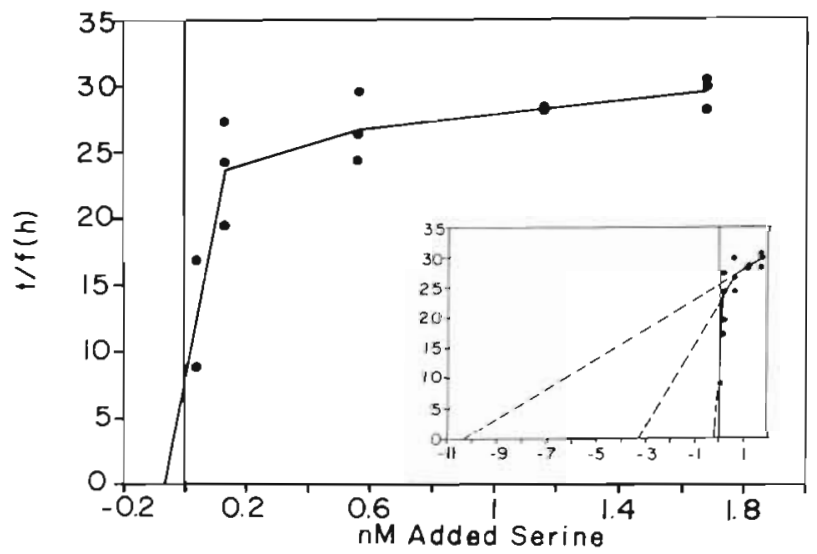

Fig. 1. Modified Lineweaver-Burke plot of apparent multiphasic kinetics of serine uptake ( 9 Feb). Inset: same data on an expanded scale to show the negative $x$-intercept values. The $\mathrm{K}_{\mathrm{t}}+\mathrm{S}_{\mathrm{n}}$ ( \pm asymptotic standard error) from non-linear regression analysis of the whole data set was $1.4 \pm 0.8 \mathrm{nM}$ (see Table 2). Black dots: individual data points

exceeded HPLC estimates of $S_{n}$ only in 9 of the 14 paired comparisons. HPLC-measured DFAA concentrations can exceed $\mathrm{K}_{1}+\mathrm{S}_{n}$ due to accidental contamination of the sample before HPLC analysis. Amino acids are ubiquitous (e.g. from fingerprints), and possible contamination sources include containers, filtration systems, and even the plankton within a water sample (Fuhrman \& Bell 1985). Given that only $2.5 \times$ $10^{-13}$ moles were injected into the HPLC when the DFAA concentration was $1 \mathrm{nM}$, it would not be surprising if some samples had contamination equivalent to a few nanomoles per liter, despite our precautions. Occasional low levels of DFAA contamination may also contribute to imprecision in the kinetics assays (poor fits to the kinetics model) at the low concentrations used in this study. Nevertheless, contamination is less likely with the kinetics assay because of less sample manipulation than with the chemical techniques (e.g. no prefiltration required).

Past studies where chromatographically-measured concentrations exceeded those inferred from biological considerations (Burnison \& Morita 1974, Dawson \& Gocke 1978) have suggested that some portion of the DFAA pool is unavailable for bacterial utpake, e.g. complexed with other dissolved material. Although our data do not eliminate this possibility, the similarity between the HPLC and kinetics results suggest that most or all of the DFAAs in our samples were available to microorganisms.

There is little utility in estimating DFAA uptake affinity constants $\left(K_{t}\right)$ for natural communities of marine bacteria based on HPLC and kinetic data at this time. For the 3 observations of mixed amino acids, $K_{t}$ (by difference) averaged $8.2 \mathrm{nM}$ (39\% of the average HPLC-measured $S_{n}$ of $22.1 \mathrm{nM}$ ). It is not possible to estimate the $K_{t}$ in those samples where the HPLC value exceeds the $K_{t}+S_{n}$, but even for samples where the HPLC value is lower, there are additional considerations. Multiphasic kinetics were found in some of the samples. With the number of replicates, substrate addition levels, and precision of our data, it was not possible to make good estimates of the individual $K_{t}$ values; a larger number of more closely-spaced concentrations would be better (Azam \& Hodson 1981, Nissen et al. 1984). Also, amino acids are taken up by both specific and non-specific uptake mechanisms, and may compete with each other to some extent for uptake (Crawford et al. 1974, Billen 1984). Therefore, the 
$\mathrm{K}_{\mathrm{t}}+\mathrm{S}_{\mathrm{n}}$ value obtained when one labeled amino acid is added reflects not only that amino acid, but also to a lesser extent the sum of all the other competing amino acids. Even though the competition among amino acids may not be very strong, the cumulative effect of several potential competitors sometimes may be significant. This is a difficult factor to correct for, although mixtures of labeled amino acids may partly avoid this problem.

It is important to note that at low added concentrations, $K_{t}+S_{n}$ approximates $S_{n}$, suggesting that $K_{t}<S_{n}$. This implies that in seawater, DFAA uptake rates were usually near $V_{\max }$ of the highest affinity uptake mechanisms. If this is so, it has implications regarding bacterial regulation and growth in seawater. Uptake systems operating near $V_{\max }$ do not have the capability to increase the uptake rate when the DFAA supply increases. Thus, for the bacterial community to be capable of responding to increased DFAAs, it must have systems with higher $V_{\text {max }}$. These higher $V_{\text {max }}$ mechanisms may be present in the same species or in species different from those active at the generally low ambient concentrations, and may partly explain the socalled bottle or nutrient enrichment effect (ZoBell \& Anderson 1936, Torella \& Morita 1981, Ferguson et al. 1984). Indeed we saw evidence for multiphasic uptake kinetics in a few of our samples, even at the low concentrations added. We suspect that all the samples would exhibit such kinetics if a broad enough range of added concentrations were tested. This has previously been found for glucose (Azam \& Hodson 1981). The existence of multiphasic kinetics may necessitate the reinterpretation of many previously published studies of DFAA uptake parameters. In those studies where the range of added substrate was much higher than ambient concentrations (commonly the case when low specific activity ${ }^{14} \mathrm{C}$ labeled DFAAs were used), it is possible that the $K_{t}$ and $V_{\text {max }}$ may have reflected those of the uptake sites that dominate at the higher experimental concentrations and not those which dominate at natural ambient levels.

In a comparison of their own kinetics assays to previously published chemical measurements of DFAAs, Ferguson \& Sunda (1984) suggested that the chemical measurements may be overestimates of DFAAs. They reported $K_{t}+S_{n}$ values for total DFAAs of coastal surface waters in the range of 2 to $7 \mathrm{nM}$, whereas published chemical measurements were about an order of magnitude higher. We found no such discrepancy here, perhaps due to improvements in both the kinetics procedure and chemical analysis. For the kinetics assay, we measured the concentrations of DFAAs in the radioactive stock solutions, rather than assuming the accuracy of the manufacturer's label. There were usually extra DFAAs (non-labeled contaminants), typi- cally at about the same level as the nominal amount, and thus, previous $K_{t}+S_{n}$ values could have been underestimates by about a factor of two. Our use of trace-metal clean techniques probably cut back on DFAA as well as trace metal contamination. For chemical analysis, we used extremely fastidious sampling and filtration techniques that minimized potential sources of contamination possibly present in previous studies. Our own preliminary HPLC measurements of offshore DFAAs indicate that concentrations can be undetectable or barely detectable $(\leq 0.5 \mathrm{nM}$ of the most concentrated individual DFAAs).

Our results further support the conclusion of Ferguson \& Sunda (1984) that addition of very low tracer levels to minimally contaminated samples demonstrates very rapid DFAA turnover in ocean waters. The Long Island Sound samples (summer) routinely had turnover times shorter than almost all those previously measured in seawater (Billen 1984); winter turnover times were relatively fast even at temperatures of 4 to $6^{\circ} \mathrm{C}$. Even though the DFAA concentrations we measured were lower and tumover rates were faster than most of those previously reported, the total DFAA utilization rates we calculated are not substantially different from many previously published rates. This is because overestimation of the size and underestimation of the tumover rate of the DFAA pool are compensating errors for flux determinations.

Acknowledgements. We thank T. M. Bell and Dr. A. V. Palumbo for assistance with experiments, the officers and crew of the R/V Researcher for their help, and C. Lee and $W$. Sunda for reviewing the manuscript. This work was supported by NSF grants OCE-8207523 and OCE-8410074 to $\mathrm{JF}$.

\section{LITERATURE CITED}

Andrews, P., Williams, P. J. leB. (1971). Heterotrophic utilization of dissolved organic compounds in the sea III. Measurement of the oxidation rates and concentrations of glucose and amino acids in seawater. J. mar. biol. Ass. U.K. 51: 111-125

Azam, F., Hodson, R. E. (1981). Multiphasic kinetics for Dglucose uptake by assemblages of natural marine bacteria. Mar. Ecol. Prog. Ser. 6: 213-222

Billen, G. (1984). Heterotrophic utilization and regeneration of nitrogen. In: Hobbie, J. E., Williams, P. J. leB. (ed.) Heterotrophic activity in the sea. Plenum Press, New York, p. 313-355

Burnison, B. K., Morita, R. Y. (1974). Heterotrophic potential for amino acid uptake in a naturally eutrophic lake. Appl. Microbiol. 27: 488-495

Crawford, C. C., Hobbie, J. E., Webb, K. L. (1974). The utilization of dissolved free amino acids by estuarine micro-organisms. Ecology 55: 551-563

Dawson, R., Gocke, K. (1978). Heterotrophic activity in comparison to the free amino acid concentrations in Baltic Sea water samples. Oceanologica Acta 1: 45-54

Ferguson, R. L., Buckley, E. N., Palumbo, A. V. (1984). 
Response of marine bacterioplankton to differential filtration and confinement. Appl. environ. Microbiol. 47: 49-55

Ferguson, R. L., Sunda, W G. (1984). Utilization of amino acids by planktonic marine bacteria: importance of clean technique and low substrate additions. Limnol. Oceanogr. 29: 258-274

Fuhrman, J. A., Azam, F. (1980). Bacterioplankton secondary production estimates for coastal waters of British Columbia, Antarctica, and California. Appl. environ. Microbiol. 39: 1085-1095

Fuhrman, J. A., Azam, F. (1982). Thymidine incorporation as a measure of heterotrophic bacterioplankton production in marine surface waters: evaluation and field results. Mar. Biol. 66: 109-120

Fuhrman, J. A., Bell, T. M. (1985). Biological considerations in the measurement of dissolved free amino acids in seawater and implications for chemical and microbiological studies. Mar. Ecol. Prog. Ser. 25: 13-21

Hagström, A.., Larsson, U., Horstedt, P., Normark, S. (1979). Frequency of dividing cells, a new approach to the determination of bacterial growth rates in aquatic environments. Appl. environ. Microbiol. 37: 805-812

Jergensen, N. O. G., Sondergaard, M. (1984). Are dissolved free amino acids free? Microb. Ecol. 10: 301-316

Li, W. K. (1983). Consideration of errors in estimating kinetic parameters based on Michaelis-Menten formalism in microbial ecology. Limnol. Oceanogr. 28: 185-190

Mopper, K., Lindroth, P. (1982). Diel and depth variations in dissolved free amino acids and ammonium in the Baltic Sea determined by shipboard HPLC analysis. Limnol. Oceanogr. 27: 336-347
Nissen, H., Nissen, P., Azam, F. (1984). Multiphasic uptake of D-glucose by an oligotrophic marine bacterium. Mar Ecol. Prog. Ser. 16: 155-160

Palumbo, A. V., Ferguson, R. L., Rublee, P. A. (1983). Efficient utilization of free amino acids by suspended marine bacteria. J. exp. mar. Biol. Ecol, 69: 257-266

Parsons, T. R., Strickland, J. D. H. (1962). On the production of particulate organic carbon by heterotrophic processes in seawater. Deep Sea Res. 8: 211-222

Parsons, T. R., Takahashi, M., Hargrave, B. (1977). Biological oceanographic processes. Pergamon Press, New York

Torella, F., Morita, R. Y. (1981). Microcultural study of bacterial size changes and microcolony and ultramicrocolony formation by heterotrophic bacteria in seawater Appl. environ. Microbiol. 41: 518-527

Williams, P. J. leB. (1981). Incorporation of microheterotrophic processes into the classical paradigm of the planktonic food web. Kieler Meeresforsch. 5 (Sonderh.): 1-28

Williams, P. J. leB., Yentsch, C. S. (1976). An examination of photosynthetic production excretion of photosynthetic products, and heterotrophic utilization of dissolved organic compounds with reference to results from a coastal subtropical sea. Mar. Biol. 35: 31-40

Wright, R. T., Hobbie, J. E. (1965). The uptake of organic solutes in lake water. Limnol. Oceanogr. 10: 22-28

ZoBell, C. E., Anderson, D. Q. (1936). Observations on the multiplication of bacteria in different volumes of stored sea water and the influence of oxygen tension and solid surfaces. Biol. Bull. mar. biol. Lab., Woods Hole 71: $324-342$

This article was presented by Professor K. Banse; it was accepted for printing on August 17, 1986 